\title{
Perceptions of Competence and the European Economic Crisis
} A Micro-level Analysis

Chiozza, Giacomo; Manzetti, Luigi

Document Version

Accepted author manuscript

Published in:

Political Research Quarterly

DOI:

10.1177/1065912915595629

Publication date:

2015

License

Unspecified

Citation for published version (APA):

Chiozza, G., \& Manzetti, L. (2015). Perceptions of Competence and the European Economic Crisis: A Microlevel Analysis. Political Research Quarterly, 68(3), 457-473. https://doi.org/10.1177/1065912915595629

Link to publication in CBS Research Portal

\section{General rights}

Copyright and moral rights for the publications made accessible in the public portal are retained by the authors and/or other copyright owners and it is a condition of accessing publications that users recognise and abide by the legal requirements associated with these rights.

Take down policy

If you believe that this document breaches copyright please contact us (research.lib@cbs.dk) providing details, and we will remove access to the work immediately and investigate your claim. 


\section{Perceptions of Competence and the European Economic Crisis: A Micro-Level Analysis \\ Giacomo Chiozza and Luigi Manzetti}

Journal article (Post print version)

CITE: Perceptions of Competence and the European Economic Crisis : A Micro-Level Analysis. / Chiozza, Giacomo; Manzetti, Luigi. In: Political Research Quarterly, Vol.

68, No. 3, 2015, p. 457-473.

DOl: http://dx.doi.org/10.1177/1065912915595629

Uploaded to Research@CBS: September 2016 


\title{
Perceptions of Competence and the European Economic Crisis: A Micro-Level Analysis*
}

\author{
Giacomo Chiozza ${ }^{\dagger}$ \\ Luigi Manzetti ${ }^{\ddagger}$
}

November 3, 2014

\section{Please do not cite without the authors' consent}

Copyright (C) 2014 by Giacomo Chiozza and Luigi Manzetti

*Authors' names are in alphabetical order. We would like to thank Carol Atkinson, Manuele Citi, and Guillermo Rosas for questions, comments, and suggestions. Mistakes, omissions, and other assorted infelicities are our own responsibility. Data, replication codes and supporting materials ałe will be available at http://www. chiozza.org.

${ }^{\dagger}$ Associate Professor of Political Science, Vanderbilt University, Department of Political Science, 230 Appleton Place, PMB 0505, Nashville, TN 37203-5721. E-mail: giacomo.chiozza@gmail.com; Website: http://www.chiozza.org.

${ }^{\ddagger}$ Professor, Copenhagen Business School, Department of Business and Politics, Steen Blichers Vej 22, DK-2000 Frederiksberg. E-mail: Im.dbp@cbs.dk. 


\title{
Perceptions of Competence and the European Economic Crisis: A Micro-Level Analysis
}

\begin{abstract}
This study provides micro-level evidence for the new theories of accountability under globalization. We analyze the micro-level logic that underpins political accountability in democratic countries with highly globalized economies. We contend that voters discount current economic conditions in evaluating incumbent leaders if they perceive the incumbent leader moving the country in the right direction. We test this argument with survey data from eight European countries in 2012, while controlling for potential alternative explanations associated with pocketbook, sociotropic, and clarityof-responsibility factors. We find that valence considerations related to future directions in the country sustain positive evaluations of leaders' performance even in the face of negative evaluations of the economy.
\end{abstract}

Supplemental materials intended for an online Appendix are included in this document starting from page 34. These materials include information on data, measurement, and descriptive statistics.

Word Count: 9018 (main text)

1002 (online appendix) 


\section{Introduction}

In 2014 Prime Minister Matteo Renzi won an outstanding victory in the European Parliament and local elections in Italy (Davies, 2014; Sala, 2014). Considering that his party had been identified by voters as supportive of unpopular austerity measures in the previous year, this was a major accomplishment. The literature on economic voting would have predicted a much worse result for Renzi. The puzzle is, then: how could Renzi pull it off?

To answer this question, we develop a theory that, building upon the insights of the new literature on accountability under globalization (Hellwig, 2001; Hellwig and Samuels, 2007; Hellwig, 2008; Cerny, 2010; Vowles and Xezonakis, 2010), explains the micro logic that voters use in assessing incumbent leaders in highly integrated democracies. In a nutshell, we argue that the voters of globalized democracies discount current economic conditions in evaluating incumbent leaders if they perceive incumbent leaders moving their countries in the right direction despite many obstacles. Put differently, if people believe that globalization is responsible for economic effects beyond the control of their national leaders and such leaders show the capability of steering their countries toward a better future making the best out of a constrained situation, then we should expect economic voting considerations to be of little importance.

We test this argument with an analysis of survey data from eight European countries in 2012. Since the financial crisis of 2008-2009, voters have not only directly experienced the harsh face of globalization, but they have also witnessed that some countries have been able cope with the crisis better than others. By evaluating how voters assessed the performance

of their leaders in dealing with the European economic crisis of 2008-2009, we identify the sources of leaders' "perceived competency" in adverse conditions under globalization.

Contrary to the wisdom of standard economic voting theory, we uncover evidence suggesting that leadership factors offset the potential negative effects of what has been the most 
severe economic crisis since the Great Depression. In and of itself, this is an important finding for those scholars interested in public opinion and voting behavior, which illustrates the new dynamics of political accountability under the vastly changed international political economy conditions of the twenty-first century. This finding can also help politicians to devise new strategies for electoral success. When voters recognize the constraints imposed by globalization on aggregate economic outcomes, successful politicians are those who can provide a vision and project that can move their countries forward, as was the case for Matteo Renzi in the 2014 European and local elections.

We proceed in four steps. First, we provide a brief overview of the literature on accountability and globalization, which then leads to the formulation of our hypotheses. Second, we describe our data and empirical strategy. We estimate a series of conditional tree models, a class of models from the statistical learning approach that is particularly appropriate to identify interaction effects (Breiman et al., 1984; Hastie et al., 2001; Hothorn et al., 2006; Strobl et al., 2009; James et al., 2013). Third, we present our findings and discuss their relations to our argument and the broader literature on accountability under globalization. In our conclusion, we assess the contributions of this study to the current academic debate and describe further avenues of research.

\section{Globalization and Accountability}

A substantial amount of literature in vote choice maintains that citizens hold incumbents accountable based upon their performance on economic issues particularly when countries go through recessions. This literature, which harks back to the foundational insights in Downs (1957)'s theory of democracy, burgeoned in the 1970s and 1980s along three major schools of thought:

- Pocketbook (or egotropic) voting refers to rational evaluations of government or incum- 
bents based upon an individual's personal financial situation rather than the country's as a whole (Fiorina, 1978);

- Sociotropic voting refers instead to rational assessments supporting or punishing a government or incumbents based upon the status of the national economy (Kiewiet, 1981; Chappell and Keech, 1985; Lewis-Beck, 1988);

- Clarity of responsibility hypothesis according to which voters hold incumbents accountable if they can clearly attribute responsibility for poor economic conditions to them (Powell and Whitten, 1993; Tavits, 2007);

These schools of thought may take a prospective view, whereby voters reward or punish governments or incumbents based upon what they expect them to do in the future on certain issues, and a retrospective view, whereby voters vote as a reaction to past performance. Over time the scholarly interest on these issues has increased tremendously. By the mid-2000s roughly four hundred academic works had appeared on economic voting alone and, despite a wide variety of results, a large majority of them have shown that the political accountability primarily responds to sociotropic rather than pocketbook considerations (Lewis-Beck and Stegmaier, 2007; Fossati, 2014).

Since the early 2000s, however, there has been an increasing debate about the effects of greater economic interdependence caused by globalization on democratic accountability. According to a series of recent studies (Hellwig and Samuels, 2007; Cerny, 2010; Bellucci et al., 2012; Ezrow and Hellwig, ming), globalization is eroding the degree to which citizens hold incumbents accountable for the state of the economy in general, and for their personal well-being in particular, as postulated by earlier works on economic voting. In the first ground-breaking study in this regard, Hellwig (2001) demonstrated that in advanced industrial societies economic openness causes sophisticated respondents to be less influenced by poor economic results in their evaluation of an incumbent government. In subsequent 
studies using different and larger data sets, several scholars confirmed that a high level of exposure to global trade weakens the impact of economic voting (Hellwig and Samuels, 2007; Hellwig, 2008; Hellwig et al., 2008; Duch and Stevenson, 2010). Moreover, in their analysis of Australia, New Zealand and several European countries Ezrow and Hellwig (ming) found that the more a country is integrated in the global economy the less responsive government parties are in responding to voters' shifts on a left-right continuum within elections. In other words, globalization is increasing the clout that market actors have over parties with governing experience at the expense of voters' preferences. Furthermore, in his examination of twenty-three members of the Organization of Economic Cooperation and Development, Steiner (2010) also determined that high levels of economic integration depress voter turnout as many citizens feel as if their vote has become meaningless.

A substantial number of studies has thus shown that in more globalized economies retrospective economic performance has no discernible impact on incumbent parties' electoral fortunes. The reasons for the disconnect between economic performance and political accountability in advanced democracies with open economies, however, are less well understood. The theoretical rationale behind the new perspectives on accountability under globalization is the influence that neoliberalism has had in policy making since the early 1980s. The adoption of supply side economics by Ronald Reagan in the United States and Margaret Thatcher in the United Kingdom progressively induced greater trade and financial liberalization and a transformation on a global scale formalized by a series of successful negotiations spearheaded by the General Agreement on Tariffs and Trade first and the World Trade Organization later (Cerny, 1990; Sperling, 2009). As a result, nation states have become less capable of manipulating economic policy in accordance to their domestic needs as it had been the case under a variety of Keynesian welfare models created after World War II and are today more subject to the constraints imposed by the free market (Mishra, 1999; Pierson, 2001). Thus, states have been forced to compete to attract capital investments demanding low taxes, fiscal 
deficits, inflation, and labor costs, which often penalize their constituencies (Andrews, 1994; Palan and with Phil Deans, 1996; Hays, 2003).

As a consequence, the disconnect between accountability and economic performance might be a consequence of "real" constraints imposed by globalization on democratic leaders' stewardship of their countries' economies. But, as Hellwig and Samuels (2007, 296-298) point out, it might also be a consequence of "voters' perceptions" of competence. In this second scenario, citizens allegedly understand the contextual constraints imposed upon their governments by economic interdependence and, therefore, they are less inclined to punish their leaders at the ballot box for poor results. Hellwig and Samuels (2007) favor the perception hypothesis, but they recognize that "aggregate analyses of economic and electoral data are unable to distinguish between these two causal mechanisms." (Hellwig and Samuels, 2007, 297)

This is the place where our argument enters the theoretical debate about globalization and accountability. We build upon the insight of Vowles and Xezonakis (2010) who argue that, as countries become more integrated into the global financial system, valence considerations dealing with leaders' evaluations of performance and competence will matter more for individual voting decisions. Thus, not only do globalization constraints matter but they also enhance people's perceptions about the competence of political leaders. Before elaborating on our argument in more detail, we recognize that there exists, however, a substantial literature that challenges the globalization argument examined so far.

Given its size, we will limit ourselves to some of the most important works. Boix (1998), for instance, argued that despite globalization states still retain considerable autonomy to promote their national interest through supply side policies. Others have contended that the effect of globalization on state capacity is mixed, and may actually prompt centerto-left government to adopt interventionist policies to compensate the negative effects of globalization (Garrett, 1998; Swank, 2002; Iversen, 2005). Indeed, even in some of the most 
integrated markets in Western Europe governments have been able to retain large welfare programs and discretion in regulating their economies. Likewise, several Latin American countries have successfully combined trade liberalization with demand-side policies bolstering the public sector role (Kurtz and Brooks, 2008). Moreover, several studies demonstrate that citizens are much more sophisticated than previously thought and are able to discern the impact of external factors from those dependent on domestically driven policy choices (Hanson et al., 2007). A more nuanced argument comes from Kayser and Peress (2012) who introduce the concept of "benchmarking" according to which voters punish or reward incumbents depending on how their country's growth rate compares with the performance of other countries.

It would be reasonable to expect that, in the aftermath of the global financial crisis of 2008-2009, the current status of the economy would be particularly salient in people's minds, which would then re-establish the traditional connection between economic performance and political accountability. If that were indeed the case, it would validate the more skeptical perspectives on the political consequences of globalization. The contribution of this study to the current academic debate is, therefore, to demonstrate that current economic conditions have played a marginal role in voters' assessments of their leaders in the specific context of the European economic crisis and to illustrate some of the micro-processes that have been transforming political accountability in globalized democracies.

\subsection{Hypotheses}

The new theories of accountability under globalization posit that the link between economic performance and incumbents' standings in voters' minds gets blurred. As political leaders lose their ability to steward their countries' economies using macro-economic policies, citizens are more inclined to give their incumbent leaders a pass for bad economic conditions. As a 
consequence, incumbents get reelected despite a bad economy (Hellwig and Samuels, 2007).

If the traditional parameters of political accountability fade in people's minds, what would, then, counts for voters? We contend that, if indeed globalization severs the connection between political agency and economic conditions, voters will evaluate their leaders on the basis of a broader array of policies and considerations. As Vowles and Xezonakis (2010) have argued, valence considerations become more important for voters' political decisions as countries get more integrated into the global economy. In our perspective, what counts for voters in globalized democracies is the perception that their leaders are able to project a vision for a better future. This perception can materialize itself in the belief that their countries are heading in the right direction, despite poor economic conditions; or it can manifest itself in a prospective evaluation of future economic conditions. Thus, rather than punish leaders for past failures or reward them for past achievements, the voters of globalized democracies focus on the future. If the new theories of accountability under globalization hold, therefore, we should expect that:

H.1 - sociotropic attitudes towards general direction of the country and about future economic situation should have a positive impact on voters' assessment of their leaders performance.

The micro logic of accountability under globalization points to a second set of parameters: the attribution of responsibility for bad economic conditions. According to Hellwig and Samuels (2007), under globalization voters come to realize that their leaders have reduced levels of competence. We capture this mechanism by looking at the attribution of responsibility for the economic crisis of recent years. Thus, voters that blame banks and financial institutions have come to recognize that governments have lost at least part of their control over the economy. Conversely, voters that instead blame their governments would still be voters who would believe that their leaders still have agency on economic matters. The 
fundamental conjecture in this argument is that political leaders can, paradoxically, shield their fortunes behind the veil of incompetence. If the new theories of accountability under globalization hold, we should, therefore, expect that among voters with a negative outlook of their countries' future:

H.2 - attribution of responsibility for current economic problems to agents other than their governments should have a positive impact on voters' assessment of their leaders performance;

In addition, the micro processes underlying the new theories of accountability under globalization also imply that among the voters with positive views of their countries' general directions and future economic situations the traditional variables that pertain to the voters' assessment of the economic situation would lose their impact. This assessment could refer to an evaluation of their own personal economic situation or to a broader evaluation of the economic situation in the country. In the first case, we would have a manifestation of pocketbook reasoning, which is usually captured by the standard question "Are you better off than four years ago?"; in the second case, we would have a form of sociotropic assessment in which people evaluate how the economy of the country as a whole is doing, which was exemplified by James Carville's famous phrase "it's the economy, stupid!" during the 1992 U.S. presidential campaign (Kinder and Kiewiet, 1981; Mansfield and Mutz, 2009; Becher and Donnelly, 2013). Thus, if the new theories of accountability under globalization hold, we should expect that among voters with a positive outlook towards the future:

H.3 - pocketbook attitudes towards personal economic conditions should have marginal impact on voters' assessment of their leaders performance;

H.4 - sociotropic attitudes towards economic conditions in the country should have a marginal impact on voters' assessment of their leaders performance. 


\section{Empirical Strategy}

Between March and April of 2012 the Pew Global Attitudes Survey interviewed representative samples of citizens in eight European countries: Britain, the Czech Republic, France, Italy, Germany, Greece, Poland, and Spain. At the time, the chief executives in power were David Cameron, Petr Nečas, Nicolas Sarkozy, Silvio Berlusconi, Angela Merkel, Lucas Papademos, Donald Tusk, and Mariano Rajoy. Some of these leaders were well ensconced in power; others were about to lose office when the survey was administered. All of them, however, had to deal with the European economic crisis that had been triggered by the global financial crisis of 2008. Thus, they were all experiencing the consequences of economic globalization for their countries and their office tenure.

As we can see in Figure 1, opinions widely diverged about the performance of eight European leaders in dealing with the crisis. The prime ministers of Poland, the Czech Republic and Greece, for example, had very few supporters: no more than a third of their respective publics believed that they were doing a fine job in dealing with the European economic crisis. Chancellor Merkel, on the other hand, received a strong endorsement for her stewardship of the German economy from her fellow citizens: about $84 \%$ of the German people thought she was doing at least a somewhat good job in dealing with the European economic crisis. In Spain, Italy, Britain, and France, instead, the general public was nearly evenly split between those who thought that their leaders had been doing well and those who thought otherwise.

While we describe in more detail the survey items we use to measure our variables in the online Appendix (available here on page A-1), we list here the indicators that measure the key variables for our hypotheses, along with the labels we use to identify them in our models.

To measure attitudes towards future directions and conditions in the country, we use the 
Figure 1: Assessment of Leader's Performance

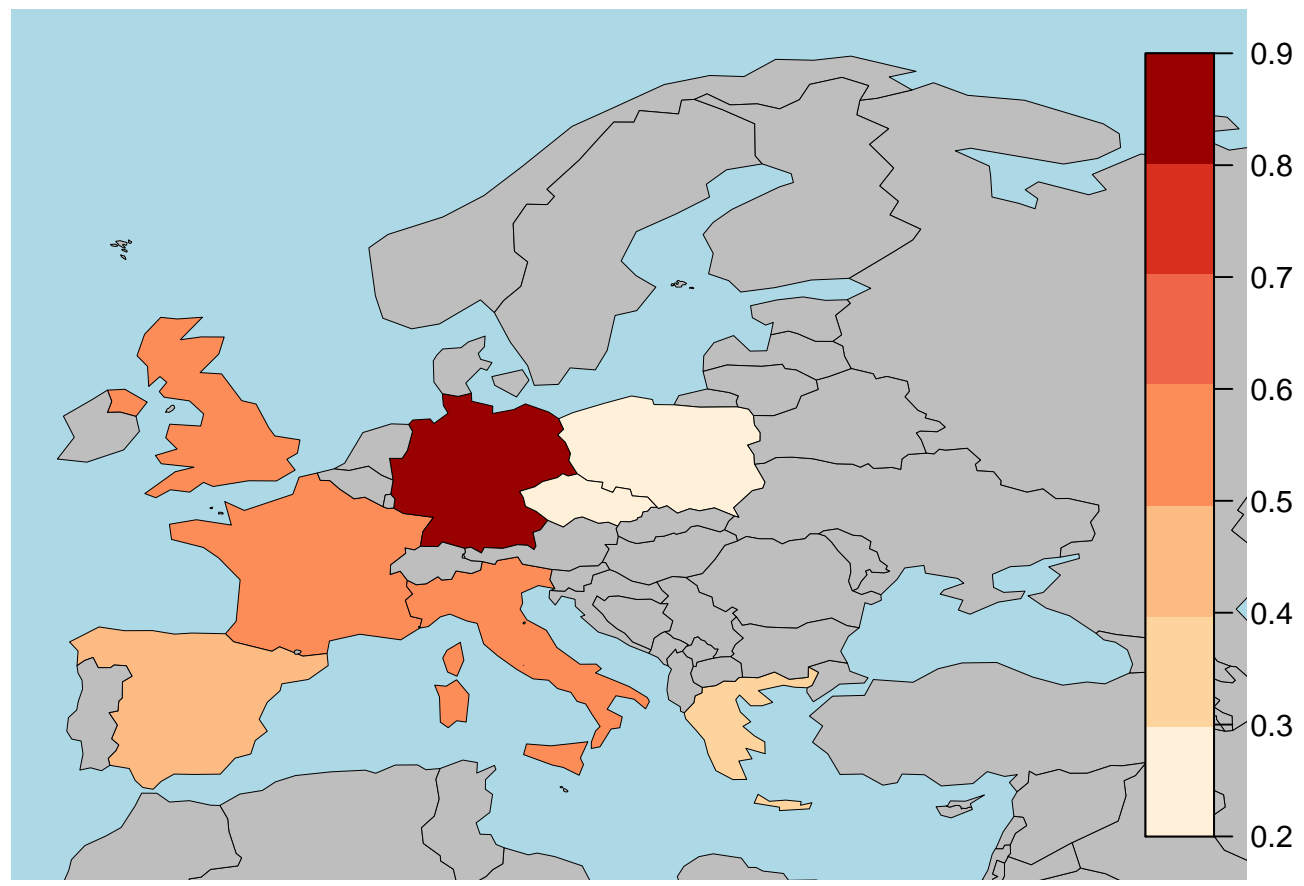

Note: Percentage of citizens who believed that the prime minister/president of their country was doing "a somewhat good" or "a very good job in dealing with the European economic crisis." Data analysis is based on the 2012 wave of the Pew Global Attitudes Survey. Countries in gray were not surveyed.

following indicators:

ECONOMY.NEXT - this variable measures whether the survey respondent believed that the economic situation in his/her country would improve, stay the same, or worsen over the next twelve months;

COUNTRY.OK - this variable measures whether the survey respondent was satisfied or not with the way things were going in his/her country. This variable serves as a catch-all measure to capture broader valence considerations given that we control for 
pocketbook and sociotropic assessment of the economy in our models.

Second, to test hypothesis H.2, we measure how the public assesses the responsibilities for the European economic crisis. The 2012 Pew Global Attitudes Survey data measure in whose hands the voters of eight European democracies would place the responsibility for the current (2012) economic crisis. The options given in the survey instrument were: a) the survey respondent's government; b) banks and other major financial institutions; c) the United States; d) the European Union; e) the public of the survey respondent's country; f) none of the above. The final option in the survey item identifies those voters who did not blame anyone because they viewed their country's economic situation in a positive way. Thus, under the clarity of responsibility hypothesis, voters would punish incumbent leaders depending upon whether they would see the government, and possibly their fellow citizens, as responsible for the bad economic conditions, while giving their leaders a pass if they would place the blame for the economic crisis on banks, the United States or the European Union, three political and economic agents with global reach and beyond the control of their leaders.

Overall, most people viewed either banks and financial institutions or their government as the main "culprits." Very few people cast blame on the United States, the European Union, their fellow citizens, or some other (non defined) agents. Still, as we show in Figure 2, there was also substantial variation across the eight countries. Banks and financial institutions were attributed the main responsibility for bad economic conditions in Britain, France, and Spain. In the Czech Republic, Greece, Italy, and Poland that responsibility fell on the government. The exception to these patterns is the German public that overwhelmingly thought their country's economy was in good shape.

Finally, to measure pocketbook attitudes towards personal economic conditions, we use the following indicators:

PERSONAL.ECONOMIC.SITUATION - this variable measures whether the survey respon- 
Figure 2: Assessment of Responsibilities for Bad Economic Conditions

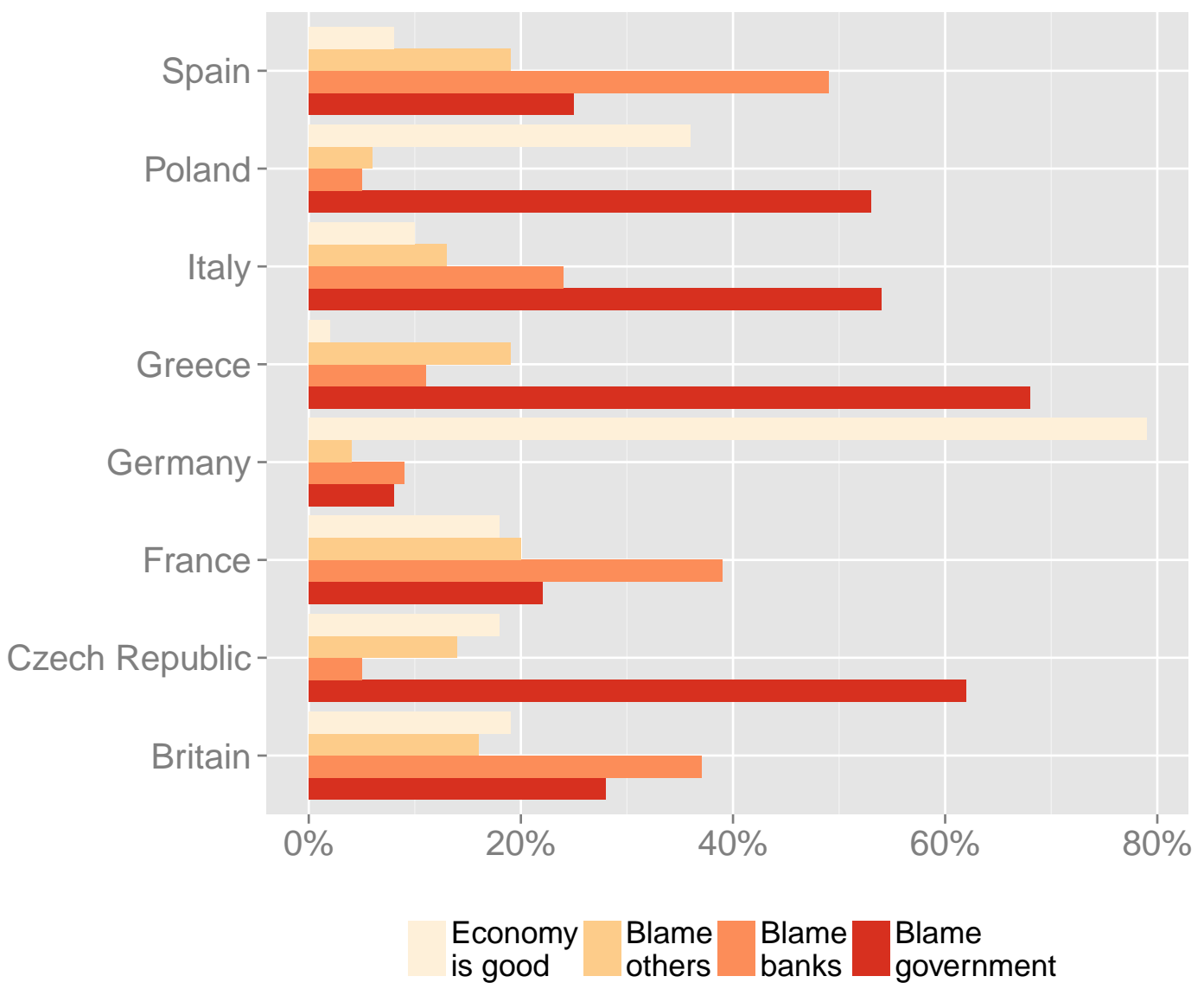

NotE: The label "Others" includes the United States, the European Union, the public of the survey respondent's country, or other non-specified agents. Data analysis is based on the 2012 wave of the Pew Global Attitudes Survey.

dent would describe his/her personal economic situation as good or bad;

DOING.BETTER.FINANCIALLY - this variable measures whether the survey respondent believed that he/she and his/her family were doing better, worse, or the same financially compared to five years prior.

To measure sociotropic attitudes towards current economic conditions, we use the following indicator: 
ECONOMY.NOW - this variable measures whether the survey respondent would describe the current economic situation in his/her country as good or bad;

\subsection{Control Variables}

We include two kinds of control variables. First, we use four different country-level variables, which measure macro-conditions that might affect voters' evaluations of the incumbent leaders. These variables capture four important dimensions that might affect the average level of voters' approval of their leaders' performance. Two of these variables are the key factors in Hellwig and Samuels (2007): a) globalization; ${ }^{1}$ b) and economic performance. ${ }^{2}$ The economies of the eight countries under investigation are highly integrated in the world economy. If we use the globalization index by Dreher et al. (2008) to rank them, they all score in the top $70 \%$ of the distribution. Still, there exists some variation, whereby Poland's and France's economies, with a score of 72.7 and 73 , respectively, are slightly less globalized than the Czech Republic's, with a score of 85.7.

As for the economic conditions, we measure the average level of economic growth in 2010 and 2011, the two years prior to the date of the Pew 2012 survey. Three of the countries in the survey experienced an economic recession, which was dramatic in the case of Greece, and milder but still painful for Italy and Spain. Britain, France and the Czech Republic were hovering at the zero growth level. Only Germany and Poland were exhibiting a decent level of growth.

The remaining two country level variables measure the political context: a) the effective number of legislative parties; ${ }^{3}$ b) and the time elapsed since the last elections. ${ }^{4}$ We conjec-

\footnotetext{
${ }^{1}$ We measure globalization using the KOF index by Dreher et al. (2008).

${ }^{2}$ Data on economic performance from the World Bank, World Development Indicators.

${ }^{3}$ Data on the effective number of legislative parties are from the Electoral Systems website at http://www . tcd.ie/Political_Science/staff/michael_gallagher/ElSystems/index.php; see also Gallagher and Mitchell (2008).

${ }^{4}$ Election dates are from the Wikipedia webpages for each country's elections.
} 
ture that the attribution of blame (or merit) to the incumbent leader would be easier in more concentrated party systems, as opposed to fragmented systems. A cohesive majority facing a cohesive opposition sharpen the attribution of responsibilities for the conduct of government affairs, which, in turn, would affect the way in which voters view the performance of their leaders. The assessment of responsibility likely responds to the timing of the electoral calendar. As elections approach, voters would gather and sort the information they need to cast their votes. Models of retrospective voting indicate that events occurring closer to election times bear more weight on the voting decision. As such, in light of the Hellwig and Samuels (2007)'s findings, the time of the electoral calendar serves as potential conditioning factor.

As we illustrate in Figure 3, however, none of the four macro-level conditions has a systematic connection with the average approval of the leader's performance in handling the European economic crisis. The coefficients on the regression lines are statistically indistinguishable from zero. As a matter of fact, most of the variation in the approval data occurs at the individual level; the Intra-class Correlation Coefficient, i.e., the amount of total variance that can be attributed to between-country variance, is $15 \%$.

Second, we include a series of variables that measure the demographic profile of the survey respondents, i.e. their gender, age, income, education, and political orientation. We also include a series of variables that measure voters' economic concerns for their country. Specifically, these variables measure whether voters viewed a) inflation, b) unemployment, c) the size of the national debt, d) the power of financial institutions and banks, or e) trade unions as a threat to the economic well-being of the country. We conjecture that this kind of economic concerns would affect both the assessment of the economic conditions and the assessment of the incumbent leaders' handling of the economic crisis.

In sum, the control variables capture an important part of the variation in people's views of their leaders' competence, which, in turn, strengthens the potential findings on the 
Figure 3: Assessment of Leader's Performance and Country Context
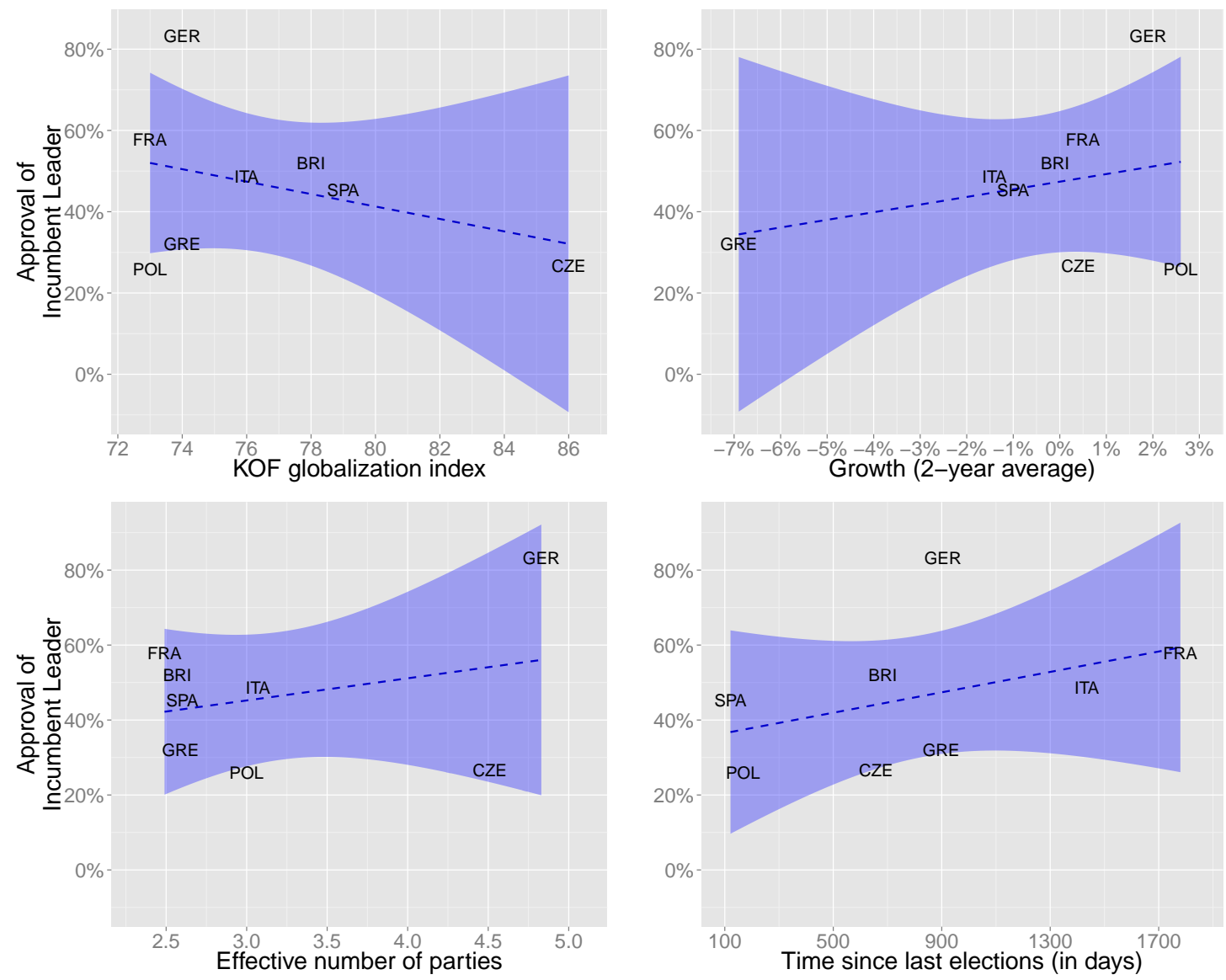

NotE: The dotted lines are regression lines from simple linear regression. The regression coefficients are statistically insignificant. Data analysis is based on the 2012 wave of the Pew Global Attitudes Survey.

variables measuring pocketbook and sociotropic attitudes towards the economy as well as the variables measuring the attribution of responsibility for the European economic crisis.

\subsection{Modeling Interactions}

A key aspect of our arguments is that globalization blurs the attribution of responsibility for bad economic conditions and, in so doing, it dilutes the accountability of incumbent leaders (Hellwig and Samuels, 2007). Despite a negative assessment of their personal or their countries' economic conditions - the thesis maintains - voters would continue to give 
support to their leaders, if they believe that their leaders have a vision for the future that is setting their countries on the right path. As a consequence, those who blame banks and financial institutions would evaluate the performance of their leaders in dealing with the European economic crisis on the basis of other parameters, which might include broader valence considerations we identified under hypothesis H.4 (Vowles and Xezonakis, 2010). At its core, our thesis is an argument about interaction effects.

To see why this is the case, let us consider a voter that claims that her financial situation has worsened over the previous five years and that views banks and financial institutions as the major agents responsible for the bad status of the economy. Let us suppose that this voter also views the incumbent leader in a negative manner. Prima facie, this would count as contradictory evidence for the new theories of accountability under globalization. On closer inspection, however, this would be a premature conclusion. It could be the case that the voter in this hypothetical example views the leader in a negative light because of other factors she would not have considered had she believed the government, and not the banks, were responsible for the bad economy.

For a more compelling test of the micro processes underpinning political accountability for the voters of globalized democracies, we would need to model how the variables that measure voters' broader valence considerations interact with the other potential drivers of voters' assessment of their leaders. In this light, then, the key underlying mechanism of the thesis posits a series of interaction effects, and can only be fully captured through empirical models that identify interaction effects.

To capture these interactions, we use a modeling strategy that is particularly adept at identifying interaction effects, i.e. recursive partitioning or conditional tree models (Breiman et al., 1984; Hothorn et al., 2006; Strobl et al., 2009). ${ }^{5}$ These are non-parametric regression

\footnotetext{
${ }^{5}$ For applications of tree models, see (De'ath and Fabricius, 2000; Kastellec, 2010; Cáceres and Malone, 2013).
} 
models that partition the data by grouping observations with a similar response profile. The partition algorithm recursively and sequentially assesses the ability of all the variables in the model to identify similar groups in the data. In so doing, conditional tree models go beyond the standard linear regression models that combine predictors in an additive manner. Instead, conditional tree models create a representation of the data that follows a if-then pattern which accommodates for interactions and non-linear relations. ${ }^{6}$

We will present models at three levels of aggregation. We begin with a simpler model that will identify the key variables that provide the best partitions in the data. We then gradually relax the level of aggregation and, thus, allow the conditional tree models to identify smaller sub-groups in the data. To guard against the risk of overfitting, i.e., the risk that the model would mistake random variation in the data for a systematic pattern, we resort to outof-sample tests (de Marchi, 2005, 34-77). We create a validation set which allocates one fourth of the observations to evaluate the predictive ability of the model, while we "grow" the tree models on the remaining $75 \%$ of the sample. The validation test set also serves as a benchmark for our robustness checks, where we compare the findings of the conditional tree models against the most common alternative for data like ours, i.e. logistic regression. Unlike logistic regression, which generates parameters on the logit scale and thus, as many papers have claimed, not immediately interpretable, an additional advantage of conditional tree models is the ease of interpretation: a) variables with explanatory power appear in the trees, while variables with weak or no association to the dependent variable are not or are relegated to lower branches in the trees; b) terminal nodes show the distribution on the dependent variable along with the number of observations in that group.

\footnotetext{
${ }^{6}$ Achen $(2005,337)$ identifies Classification and Regression Tree models as a solution to the problems common to regression modeling in political science where non-linear relations and interactions are pervasive.
} 


\section{Findings}

In Figure 4, we present the first conditional tree model, where we set the minimum number of observations in a final node to 1000. The model identifies two variables, and three groups. First, at node 1, at the top of the tree, the variable that best sorts survey respondents is the sociotropic indicator measuring whether people were satisfied with the way things were going in their countries. If that was the case, they overwhelmingly believed that the incumbent leaders were doing a good job in handling the European economic crisis: about $80 \%$ held that view. Conversely, those who were dissatisfied with the direction their countries were going formed their opinion of their leaders' performance on the basis of a prospective evaluation of the future status of the economy. Those who believed that the economic situation in their countries would get worse were less sanguine about the competency of their leaders: only $30 \%$ thought the incumbents were doing a good job in addressing the European economic crisis. Among those who thought the economic situation would stay the same or improve in the future, the evaluation of the incumbent leaders' competence in addressing the economic crisis was a "toss-up:" about $50 \%$ of the people had a positive view and about $50 \%$ of the people had a negative view of their leaders' competence.

The model in Figure 4 identifies large aggregations. But even at this level, we find evidence in support of the theory of accountability under globalization. None of the indicators associated with the traditional theories of political accountability emerged as a primary explanatory factor, in line with hypotheses H.3 and H.4. Importantly, as articulated in hypothesis H.1, sociotropic attitudes towards general conditions in the country shape voters' views. If we reduce the number of observations allowed in a final node, we are in a position to identify smaller and more precise groups and, in the process, we can evaluate the micro logic that underpins voters' decision calculus in more detail. In Figure 5, we set the number of observations in the final nodes to 500. The model continues to have the CounTRY.OK and 


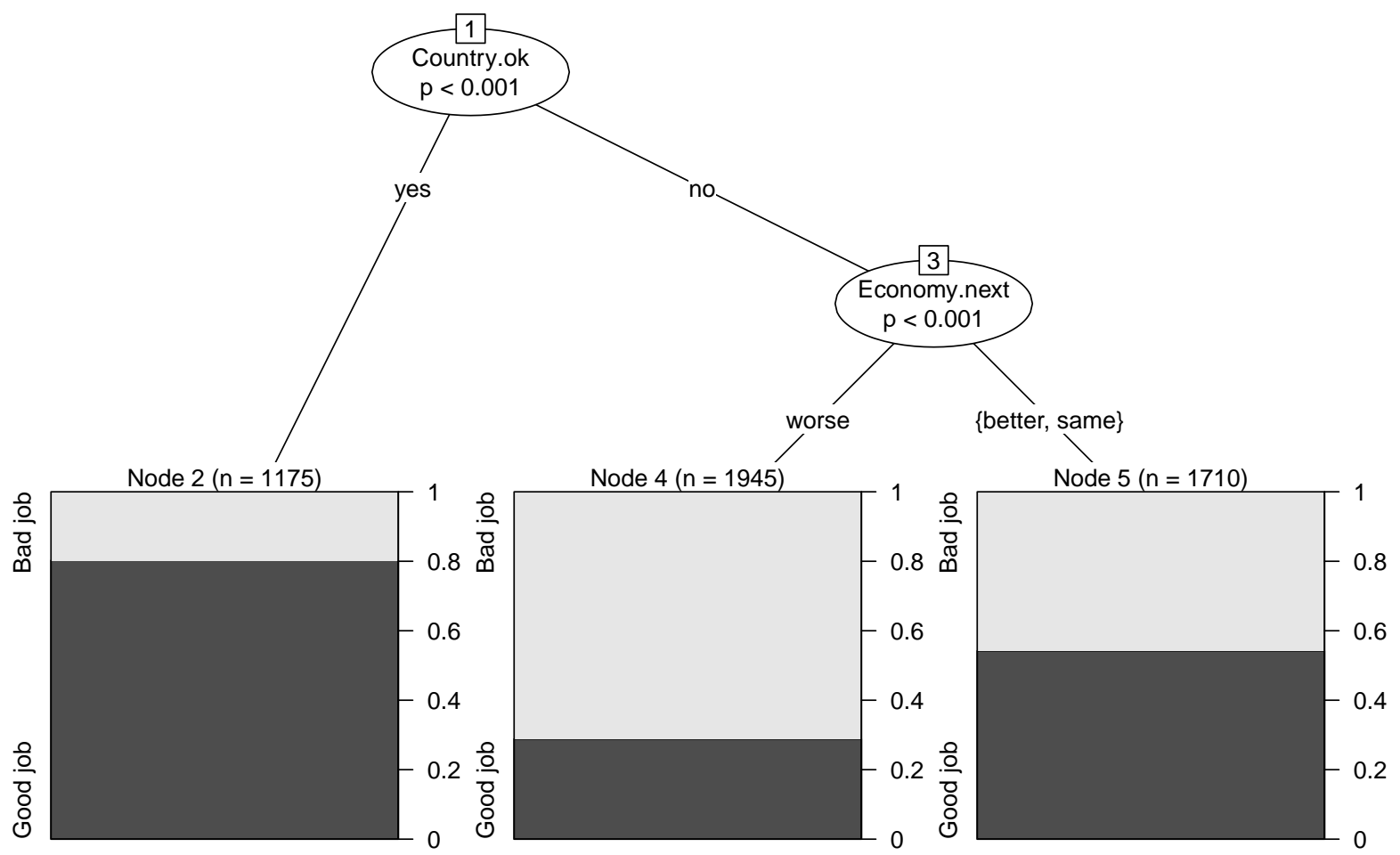

NoTE: "Good job" identifies the citizens who believed that the prime minister/president of their country was doing "a somewhat good" or "a very good job in dealing with the European economic crisis." "Bad job" identifies the citizens who believed that the prime minister/president of their country was doing "a somewhat bad" or "a very bad job in dealing with the European economic crisis." Data analysis is based on the 2012 wave of the Pew Global Attitudes Survey.

ECONOMY.NEXT variables as its most important predictors. As we proceed further down in the tree model, however, we can deliver an important result.

First, starting from the left side of Figure 5, we identify the respondents who thought their countries were heading in the right direction. This group then forms its opinion on the basis of their assessment of the current economic situation in their countries. Unsurprisingly, those who viewed the current economic situation positively also predominantly agreed that their leaders were doing a good job in handling the crisis: about $90 \%$ of the people in node 4 held such a view. What is more interesting, however, is the assessment of the incumbent leaders' 
Figure 5: Conditional Tree Model: Medium Aggregation

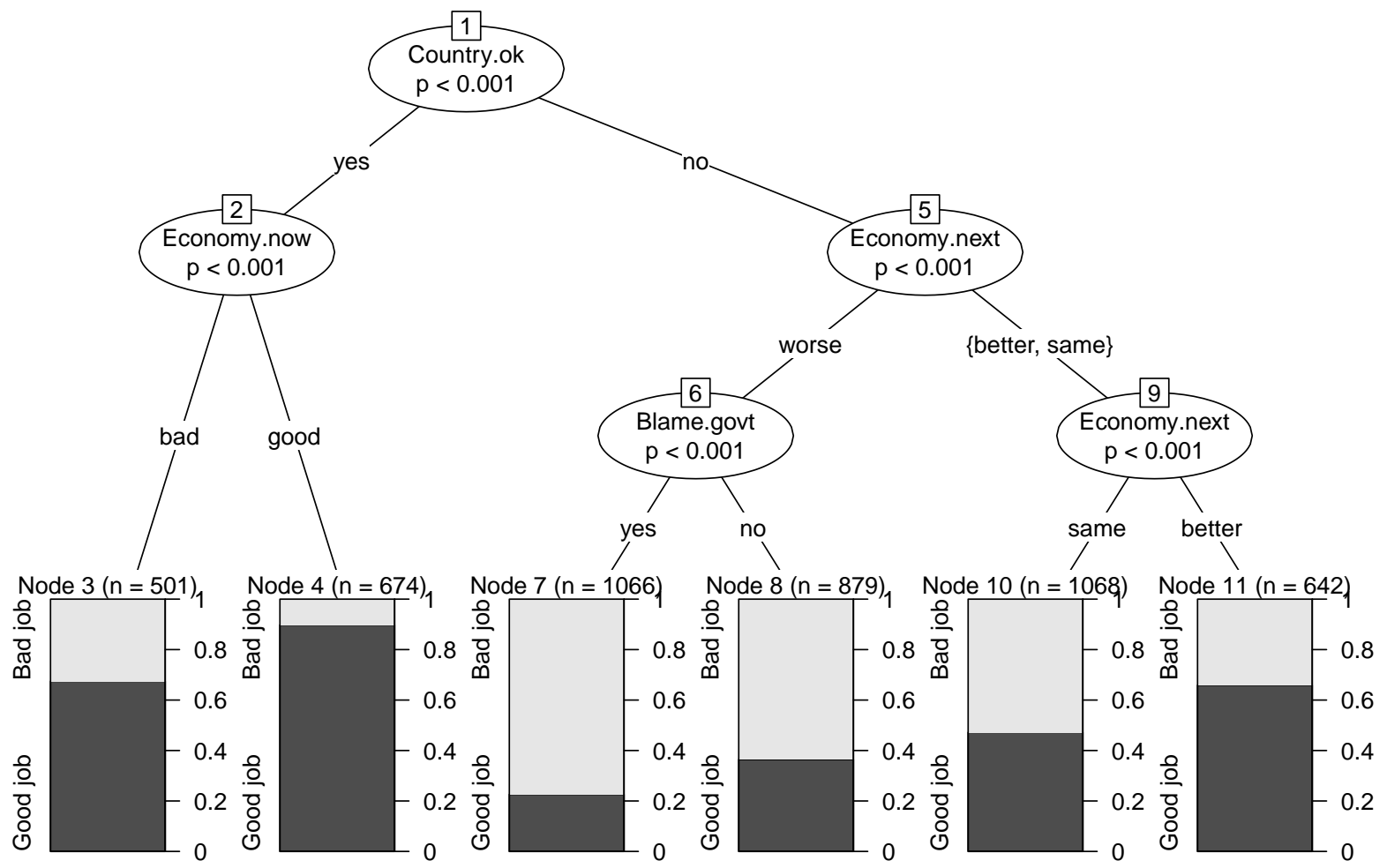

NoTE: "Good job" identifies the citizens who believed that the prime minister/president of their country was doing "a somewhat good" or "a very good job in dealing with the European economic crisis." "Bad job" identifies the citizens who believed that the prime minister/president of their country was doing "a somewhat bad" or "a very bad job in dealing with the European economic crisis." Data analysis is based on the 2012 wave of the Pew Global Attitudes Survey.

competence among the respondents who viewed the current economic situations negatively (node 3). Despite their belief that the current economic situation of their countries was "bad," about two thirds of the respondents still approved of their leaders' job in handling the crisis.

This finding illustrates the kind of interaction effects that shape voters' assessment of their leaders in globalized economies. The sociotropic assessment of current economic conditions does not carry much weight in evaluating leaders' competence, as long as voters are satisfied with the general direction of their countries. Consistently with the aggregate results on 
voting patterns by Hellwig and Samuels (2007), our models show that at the micro-level voters discount economic conditions in their evaluations of their leaders to such an extent they predominantly continue to view them as competent leaders even on economic matters, provided that the country in general is heading in the right direction. In other words, as Vowles and Xezonakis (2010) had found, broader valence considerations - in this case, about the future direction of the country - gain importance in people's political attitudes.

On the right side of Figure 5, we have an additional finding that gives further support to the portrayal of the political consequences of globalization for political accountability. In node 11, we have the voters who were dissatisfied with the general directions of their countries but were confident that the economic situation would improve. About two thirds of the respondents in this condition thought that their leaders were doing a good job in handling the economic crisis. If voters thought that the economic situation would not change in the future (node 10), they would be nearly as likely to approve of their leaders' competence as they were to be critical of it. In nodes 7 and 8, we find the voters with an overall negative orientation: for them, the country would be heading in the wrong direction and the economic situation would get worse in the future. Unsurprisingly, these voters predominantly ranked their leaders' competence in a negative way. That was overwhelmingly the case, if they blamed the government for the current economic woes. Importantly, if they attributed the responsibility of the current negative economic conditions to other agents but the government, the approval of their leaders' handling of the economic crisis increased by about 14 percentage points, from $22.6 \%$ to $36.4 \%$. As the responsibility for the economy gets disconnected from the government in voters' minds, in line with hypothesis H.2, the evaluation of the incumbents' performance receives a positive, albeit small, boost.

In Figure 6, we present an additional model where we set the minimum number of observations in the final nodes to 250 , thus identifying even more fine grained groups. We find that AGE becomes a predictor among the more optimistic voters (in node 4): nearly all 
of the voters who were 44 or older approved of their leaders' performance in addressing the economic crisis. Substantively, the interpretation of the model does not change.

Among the survey respondents who disliked the general direction of their countries, we find that two individual-level variables, AGE and PoLiticAL.VIEWs, and two country-level variables, Avg.GROWTH.2YRS and Time.SINCE.LAST.ELECTIONS, account for the variation on the dependent variable. In node 18, we find again that the attribution of responsibility for the current economic crisis to agents that are not the government, gives the incumbents a boost in their performance assessment. In nodes 9, 10 and 14, we also gain a more nuanced assessment of the clarity of responsibility hypothesis. Specifically, in node 14, the model distinguishes respondents on the basis of the electoral calendar variable. In our sample, for three countries time since the last elections had been longer than 898 days: Germany, Italy and France. Thus, in node 16, we illustrate that for the Germans, Italians and French who did not blame their governments for the current negative economic situations the probability of approval of the incumbent leader's performance was about $51.7 \%$. In the remaining five countries, the probability was about 24.3 percentage points lower.

In nodes 9 and 10, the model partitions the survey respondents who blamed the government on the basis of their political orientation and the average growth rates of their economies. Those on the left or who refused to declare their political orientation ${ }^{7}$ predomi- $^{-}$ nantly ranked their leaders' performance negatively; those on the right or the center of the political spectrum were more inclined to rank their leaders' economic performance if they lived in Greece, Italy or Spain, i.e. the three countries in the sample that experienced an average growth rate lower or equal to $-1 \%$ in 2010 and 2011.

Finally, in none of the models do the variables measuring pocketbook assessments of economic conditions appear as effective predictors. This is also additional evidence for the theory of accountability under globalization, which is consistent with hypothesis H.3. In sum,

\footnotetext{
${ }^{7}$ That was a predominant occurrence in Italy, Greece and Poland.
} 


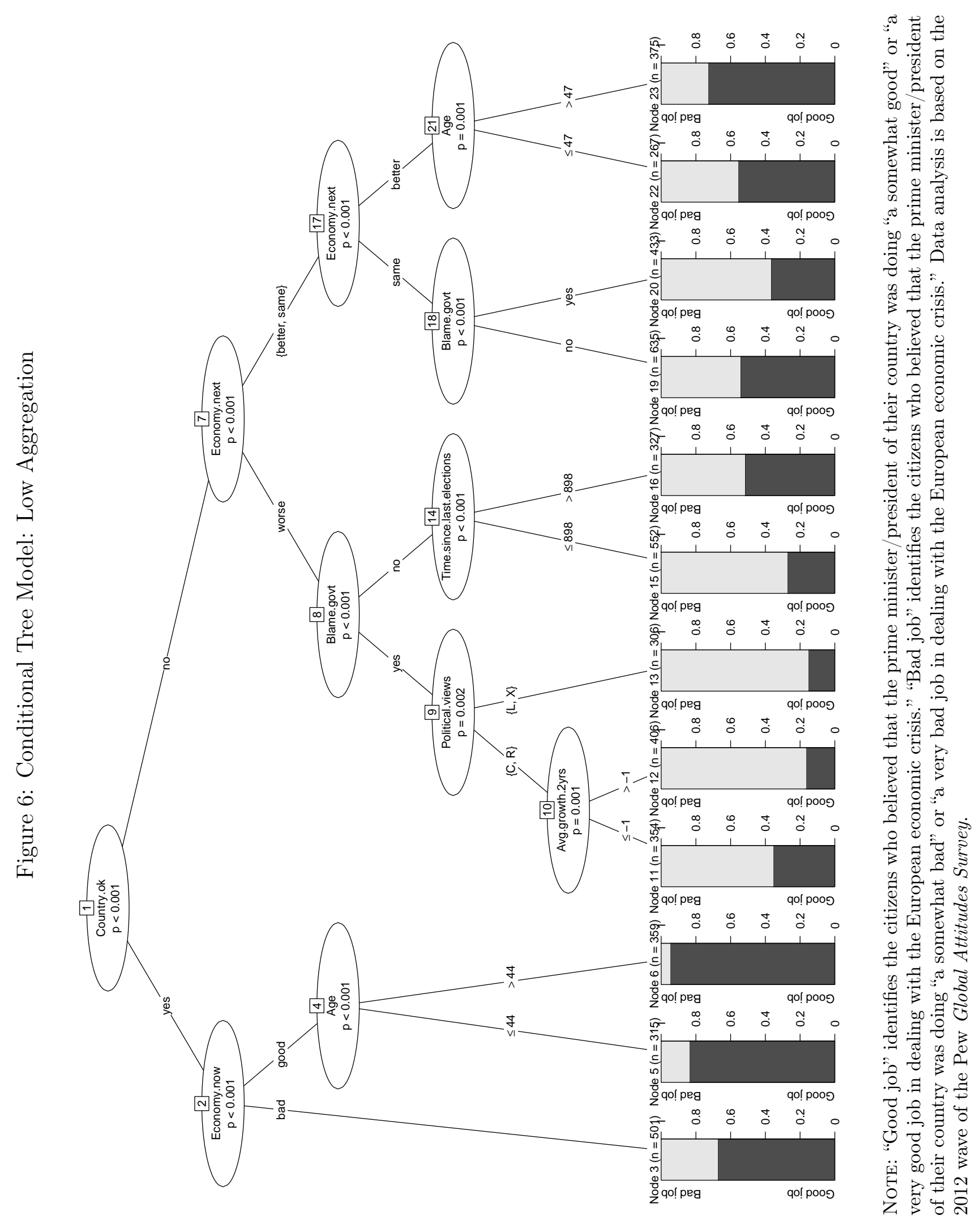


the political assessment of leaders' performance in handling the European economic crisis reflects both the decreasing relevance of current economic conditions and the increasing importance of broader valence issues in assessing how competent leaders are. At the microlevel, therefore, we find evidence that confirms the aggregate patterns that have shown the disconnection of political accountability and economic performance in globalized economies.

\subsection{Model-Based Geographic Distribution of Approval}

From the analysis of the conditional tree models, we have derived a series of theoretical statements about the dynamics of political accountability under globalization. Voters evaluate their leaders' performance in a manner that discounts the current status of the economy while giving more importance to broader valence considerations about the general direction of their countries. Incumbent leaders obtain a negative evaluation of their performance among voters who believe their countries are going in the wrong direction, predict that the future status of the economy will worsen and blame the government for this state of affairs.

Given these results, the next step is to assess how these dynamics are distributed geographically. To do so, in Figure 7, we use "bubble plots" to map the distribution of the six categories identified in the terminal nodes in Figure 5. There are eight "bubbles" on the map, one per country, which are coded by size and color. The size is proportional to the size of each country's population that falls into each given category. The color reports the probability that voters in that category would rank the incumbent leaders' performance in a positive manner. ${ }^{8}$

Starting from the top left panel, we first report the geographic distribution of the citizens most supportive of their leaders' performance, namely those that fell into Node 4 in Figure 5.

\footnotetext{
${ }^{8}$ We use a color palette that encompasses gradations of red and orange whereby dark red indicates high levels of approval of the incumbent's job and light sand indicates low levels of approval of the incumbent's job.
} 
Figure 7: Geographic Distribution of Leaders' Approval
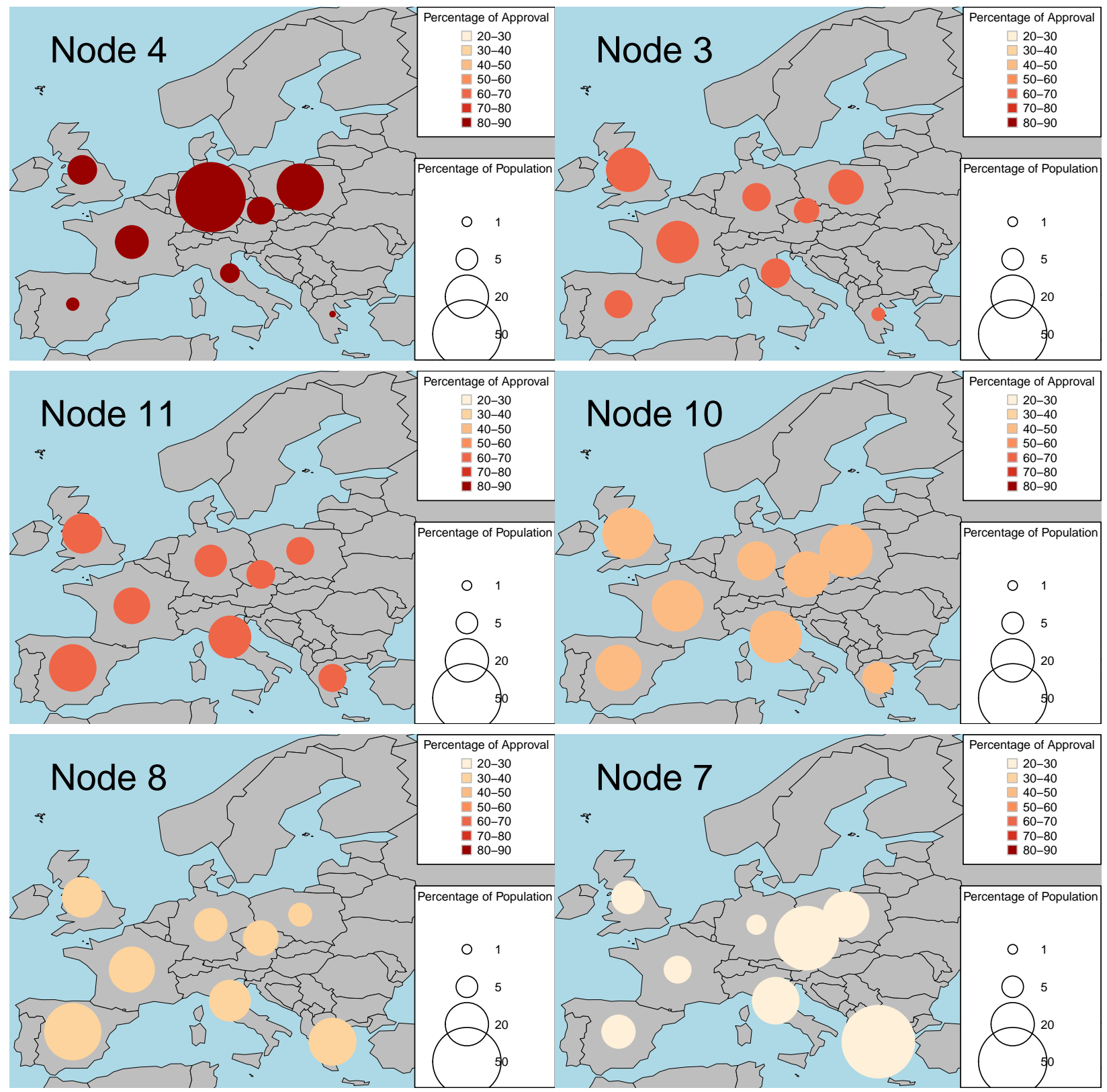

Note: Nodes and percentage of approval corresponds to those found in the conditional tree model in Figure 5. Data analysis is based on the 2012 wave of the Pew Global Attitudes Survey.

These are the citizens that approve of their country's general direction, view the current status of the economy in a positive way and, thus, give an enthusiastic endorsement to their leader's handling of the economic crisis. We find that citizens with this profile are 
predominantly in Germany: about $51 \%$ of the German population falls into Node 4 . The number of voters in Node 4 is smaller in all other countries, and infinitesimal in Greece. Poland is a partial exception: a sizeable $22.8 \%$ of Polish citizens falls in this category.

In the lower right panel of Figure 7, instead, we find the geographic distribution of the citizens that were most dissatisfied with their leaders' performance in handling the European economic crisis. These voters would blame the government for the crisis, would predict a worsening of economic conditions, and would disapprove of their country's general direction. They would also be overwhelmingly critical of how their leaders have been handling the economic crisis. The great bulk of these pessimistic citizens are in Greece (56.3\%) and in the Czech Republic (43.2\%).

In the remaining panels, we have different gradations of approval of the leaders' performance. In Node 3 and Node 11, we find voters that, for different reasons, reach on average a similar conclusion on their leaders, i.e., they approve of their leaders' performance with a $2 / 3$ chance. In particular, the citizens under Node 3 are those that approve of their leaders' performance despite a bad economy because they believe their country is heading in the right direction. About 19.9\% of the British people and about $18.4 \%$ of the French are in this group. In Node 10 and Node 8, we find voters that are more likely to disapprove of their leaders' performance than approve of it. About $28 \%$ of citizens in Britain, France, Italy and Poland fell under Node 10. About 33.8\% Spaniards were placed in Node 8.

Overall, then, our models trace back the special conditions that existed, for different reasons, in Germany and Greece, while portraying how the citizens of the eight European countries under investigation assessed their leaders' performance. If blaming the government for a bad economy is an indication of the traditional hypothesis about political accountability and clarity of responsibility, then, we have documented that such an hypothesis was mostly at work in Greece and the Czech Republic. In the other six European countries, political accountability predominantly operated under the new logic of globalization that Hellwig and 
Samuels (2007) and Vowles and Xezonakis (2010) had originally identified.

\subsection{Out-of-Sample Model Assessment}

Table 1: Out-of-Sample Performance Indicators

\begin{tabular}{|lcc|}
\hline & Conditional Tree Model & Logistic Regression Model \\
\hline Accuracy & 0.692 & 0.705 \\
95 percent CI & $0.669-0.714$ & $0.682-0.727$ \\
No information rate & 0.521 & 0.521 \\
p-value [Acc $>$ NIR] & $<0.001$ & $<0.001$ \\
Sensitivity & 0.776 & 0.67 \\
Specificity & 0.614 & 0.737 \\
\hline
\end{tabular}

The models in Figures 4 through 6 deliver important results in an intuitive manner. The algorithm of conditional tree models, however, is "greedy," i.e. it chooses the best split at each step in the process (Breiman et al., 1984; Berk, 2006). Thus, the models run the risk of overfitting the data, i.e. find relationships where there is idiosyncratic random variation. To avoid this risk, we assess the models on the basis of their out-of-sample predictive ability. Models that overfit would perform poorly out-of-sample because they would be based on an erroneous portrayal of the dynamic and causal processes that generate the data (James et al., 2013, Kindle loc: 1111-1209).

We use a randomly selected validation set, which is about one fourth of the original sample and which preserves the relative size of each country's sample. We focus on three measures: a) accuracy, i.e., the proportion of true positives and true negatives identified by the model in the validation set; b) sensitivity, i.e., the proportion of true positives; and c) specificity, i.e. the proportion of true negatives (Kuhn and Johnson, 2013, Kindle loc: 6675-6736). We compare the performance of the conditional trees against the performance of logistic regression to have a benchmark of their fit against the most common alternative modeling choice. ${ }^{9}$

\footnotetext{
${ }^{9}$ The results from the logistic regression model are reported in the online Appendix (on page A-8 in this
} 
As we show in Table 1, conditional regression trees perform very well. Their accuracy is about $17.1 \%$ higher than the baseline no information rate, i.e. the largest class percentage in the data. Specificity and sensitivity are also very high: about $77.6 \%$ of the respondents who approved of their leaders' performance are identified by the tree model as such in the out-of-sample validation test set; about $61.4 \%$ of those who disapproved of their leaders' performance were correctly identified. Importantly, these performance measures are nearly identical to those of logistic regression, which strengthens the confidence in the ability of the simpler conditional tree models to capture the key processes underlying the data.

\section{Conclusions}

A substantial amount of the scholarly literature on vote choice argues that economic issues are paramount in shaping people's preferences, particularly during economic downturns, as epitomized by James Carville's famous "It's the economy stupid!" during the 1992 U.S. presidential elections. However, the growing economic interdependence has led several scholars to question the impact of incumbents' performance in an increasing globalized world.

Indeed, new theories of political accountability under globalization maintain that voters discount the current status of the economy in assessing the performance of their leaders (Hellwig and Samuels, 2007; Cerny, 2010; Ezrow and Hellwig, ming). Voters seem to recognize that under globalization, governments have reduced competency and, therefore, evaluate their leaders on the basis of other parameters. More to it, as economic issues decline in salience valence considerations based upon the evaluations of leaders' competence become more important.

In this paper, we scrutinized such a nexus by analyzing the political impact of the aftermath of the 2008-2009 economic crisis in eight European democracies, which display varying document). 
degrees of insertion in the global economy. Consistent with the economic voting literature, we should have observed economic issues as being paramount in shaping respondents' evaluations of their leaders. However, this did not turn out to be the case.

Instead, two factors were prominent in voters' minds in 2012: a) the general direction of their countries; and b) the prediction about the future status of the economy. A negative assessment of the current status of the economy did not alter an overall positive evaluation of the leaders' performance, if voters believed the country was heading in the right direction. Hellwig and Samuels (2007)'s conjecture about the relevance of voters' perception of competence finds confirmation in a least likely scenario. Whereas previous studies found evidence in this regard at the aggregate data level, the contribution of our analysis to the ongoing debate has been to uncover the micro-level evidence about the importance of valence and leadership considerations in the dynamics of political accountability in globalized democracies. Obviously, the limited time frame and number of countries examined caution against sweeping generalizations. Nonetheless, the study's findings are intriguing enough to explore whether they can stand the test of further inquiries in the European case (as well as other regions of the world) once more data becomes available. In fact, countries around the world are likely to become increasingly interdependent in terms of trade and financial flows. This, in turn, will undoubtedly have lasting effects on people's perceptions about what their leaders' capabilities can actually do to shape their own domestic agenda. 


\section{References}

Achen, C. H. (2005). Let's put garbage-can regressions and garbage-can probits where they belong. Conflict Management and Peace Science, 22(4):327-339.

Andrews, D. M. (1994). Capital mobility and state autonomy: Towards a structural theory of international moneteary relations. International Studies Quarterly, 38(2):193-218.

Becher, M. and Donnelly, M. (2013). Economic performance, individual evaluations, and the vote: Investigating the causal mechanism. Journal of Politics, 75(4):968-979.

Bellucci, P., Costa Lobo, M., and Lewis-Beck, M. S. (2012). Economic crisis and elections: The European periphery. Electoral Studies, 31(3):469-471.

Berk, R. A. (2006). An introduction to ensemble methods for data analysis. Sociological Methods \& Research, 34(3):263-295.

Boix, C. (1998). Political Parties, Growth, and Equality. Conservative and Social Democratic Strategies in the World Economy. Cambridge University Press, New York.

Breiman, L., Friedman, J., Stone, C. J., and Olshen, R. (1984). Classification and Regression Trees. Chapman \& Hall/CRC, Boca Raton, FL.

Cáceres, N. and Malone, S. W. (2013). Forecasting leadership transitions around the world. International Journal of Forecasting, 29(4):575-591.

Cerny, P. G. (1990). The Changing Architecture of Politics: Structure, Agency, and the Future of the State. Sage, London.

Cerny, P. G. (2010). Rethinking World Politics: A Theory of Transnational Neopluralism. Oxford University Press, New York.

Chappell, H. and Keech, W. R. (1985). A new view of political accountability for economic performance. American Political Science Review, 79(2):10-27.

Davies, L. (2014). Italy's democratic party scores stunning win at european elections. The Guardian.

de Marchi, S. (2005). Computational and Mathematical Modeling in the Social Sciences. Cambridge University Press, New York.

De'ath, G. and Fabricius, K. E. (2000). Classification and regression trees: A powerful yet simple technique for the analysis of complex ecological data. Ecology, 81(11):3178-3192.

Downs, A. (1957). An Economic Theory of Democracy. Harpers and Collins, New York.

Dreher, A., Gaston, N., and Martens, P. (2008). Measuring Globalisation: Gauging Its Consequences. Springer, New York. 
Duch, R. M. and Stevenson, R. (2010). The global economy, competency, and the economic vote. Journal of Politics, 72(1):105-123.

Ezrow, L. and Hellwig, T. (Forthcoming). Responding to voters or responding to markets? Political parties and public opinion in an era of globalization. International Studies Quarterly, $\mathrm{XX}(\mathrm{XX}): \mathrm{XX}$.

Fiorina, M. P. (1978). Economic retrospective voting in american national elections: A micro-analysis. American Journal of Political Science, 22(2):426-443.

Fossati, D. (2014). Economic vulnerability and economic voting in 14 OECD countries. European Journal of Political Research, 53(1):116-135.

Gallagher, M. and Mitchell, P., editors (2008). The Politics of Electoral Systems. Oxford University Press, New York.

Garrett, G. (1998). Partisan Politics in the Global Economy. Cambridge University Press, New York.

Hanson, G. H., Scheve, K., and Slaughter, M. J. (2007). Public finance and individual preferences over globalization strategies. Economics 6 Politics, 19(1):1-33.

Hastie, T., Tibshirani, R., and Friedman, J. (2001). The Elements of Statistical Learning: Data Mining, Inference and Prediction. Springer, New York.

Hays, J. C. (2003). Globalization and capital taxation in consensus and majoritarian democracies. World Politics, 56(1):79-113.

Hellwig, T. (2008). Globalization, policy constraints, and vote choice. Journal of Politics, $70(4): 1128-1141$.

Hellwig, T. and Samuels, D. (2007). Voting in open economies: The electoral consequences of globalization. Comparative Political Studies, 40(3):283-306.

Hellwig, T. T. (2001). Interdependence, government constraints, and economic voting. Journal of Politics, 63(4):1141-1162.

Hellwig, T. T., Ringsmuth, E. M., and Freeman, J. R. (2008). The American public and the room to maneuver: Responsibility attributions and policy efficacy in an era of globalization. International Studies Quarterly, 52(4):855-880.

Hothorn, T., Hornik, K., and Zeileis, A. (2006). Unbiased recursive partitioning: A conditional inference framework. Journal of Computational and Graphical Statistics, 15(3):651674 .

Iversen, T. (2005). Capitalism, Democracy, and Welfare. Cambridge University Press, New York. 
James, G., Witten, D., Hastie, T., and Tibshirani, R. (2013). An Introduction to Statistical Learning with Applications in R. Springer, New York.

Kastellec, J. P. (2010). The statistical analysis of judicial decisions and legal rules with classification trees. Journal of Empirical Legal Studies, 7(2):202-230.

Kayser, M. A. and Peress, M. (2012). Benchmarking across borders: Electoral accountability and the necessity of comparison. American Political Science Review, 106(3):661-684.

Kiewiet, D. R. (1981). Policy-oriented voting in response to economic issues. American Political Science Review, 75(2):448-459.

Kinder, D. R. and Kiewiet, D. R. (1981). Sociotropic politics: The American case. British Journal of Political Science, 11(2):129-161.

Kuhn, M. and Johnson, K. (2013). Applied Predictive Modeling. Springer, New York.

Kurtz, M. J. and Brooks, S. M. (2008). Embedding neoliberal reform in Latin America. World Politics, 60(2):231-280.

Lewis-Beck, M. S. (1988). Economics and Elections: The Major Western Democracies. University of Michigan Press, Ann Arbor, MI.

Lewis-Beck, M. S. and Stegmaier, M. (2007). Economic models of voting. In Dalton, R. J. and Klingemann, H.-D., editors, The Oxford Handbook of Political Behavior, chapter 27, pages 518-537. Oxford University Press, New York.

Mansfield, E. D. and Mutz, D. C. (2009). Support for free trade: Self-interest, sociotropic politics, and out-group anxiety. International Organization, 63(3):425-457.

Mishra, R. (1999). Globalization and the Welfare State. Edward Elgar, Northampton, MA.

Palan, R. and with Phil Deans, J. A. (1996). State Strategies in the Global Political Economy. Pinter, New York.

Pierson, P. (2001). Coping with permanent austerity : Welfare state restructuring in affluent democracies. In Pierson, P., editor, The New Politics of Welfare State, chapter 13, pages 410-456. Oxford University Press, New York.

Powell, G. B. J. and Whitten, G. D. (1993). A cross-national analysis of economic voting: Taking account of the political context. American Journal of Political Science, 37(2):391414.

Sala, A. (2014). Renzi stravince il «derby» con Grillo; Pd al 40.8\%, M5S 20 punti indietro. Corriere della Sera, 25 May 2014. 
Sperling, V. (2009). Altered States: The Globalization of Accountability. New York. Cambridge University Press.

Steiner, N. D. (2010). Economic globalization and voter turnout in established democracies. Electoral Studies, 29(3):444-459.

Strobl, C., Malley, J., and Tutz, G. (2009). An introduction to recursive partitioning: Rationale, application, and characteristics of classification and regression trees, bagging, and random forests. Psychological Methods, 14(4):323-348.

Swank, D. (2002). Global Capital, Political Institutions, and Policy Change in Developed Welfare States. Cambridge University Press, New York.

Tavits, M. (2007). Clarity of responsibility and corruption. American Journal of Political Science, 51(1):218-229.

Vowles, J. and Xezonakis, G. (2010). From positional to valence issues? ideology, leadership, globalization, and electoral choice. Paper delivered at the Elections, Public Opinion, and Parties (EPOP) Conference, University of Essex, September 10-12 2010. 


\section{Online Appendix}

\section{Perceptions of Competence and the European Economic Crisis: A Micro-Level Analysis}

Giacomo Chiozza

Luigi Manzetti 


\section{Data and Measurement}

We analyze the 2012 wave of the Global Attitudes Survey from the Pew Foundation, which can be downloaded from http://www. pewglobal.org/. We analyze data from eight countries: Britain, the Czech Republic, France, Germany, Greece, Italy, Poland, and Spain. Sample selection is determined by the fact that the survey instrument for our dependent variable was administered in these eight countries only.

\section{Dependent Variable}

- LEADER.JOB: coded from Survey item Q42; "And how good a job is (INSERT) doing in dealing with the European economic crisis? Is (INSERT) doing a very good job, a somewhat good job, a somewhat bad job or a very bad job?" Options for each country respectively: "a) British Prime Minister David Cameron; b) German Chancellor Angela Merkel; c) French President Nicolas Sarkozy; d) (Survey country leader) [Ask in Czech Republic, Greece, Italy, Poland, Spain only]."

\section{Individual-Level Variables}

- Country.ok: coded from Survey item Q2: "Overall, are you satisfied or dissatisfied with the way things are going in our country today?"

- Economy.now: coded from Survey item Q14: "Now thinking about our economic situation, how would you describe the current economic situation in (survey country) - is it very good, somewhat good, somewhat bad or very bad?"

- ECOnOmy.next: coded from Survey item Q15: "And over the next 12 months do you expect the economic situation in our country to improve a lot, improve a little, remain the same, worsen a little or worsen a lot?" 
- Personal.economic.Situation: coded from Survey item Q18: "Now thinking about your personal economic situation, how would you describe it âĂŞ is it very good, somewhat good, somewhat bad or very bad?"

- Doing.Better.financially: coded from Survey item Q20: "And thinking about how you and your family were doing financially five years ago: Would you say you are better off today than you were five years ago, worse off today than you were five years ago, or are you doing about the same today as you were five years ago?"

- Political.views: coded from Survey item Q165: "Some people talk about politics in terms of left, center and right. On a left-right scale from 0 to 6 , with 0 indicating extreme left and 6 indicating extreme right, where would you place yourself?"

- BANKS.THREAT: coded from Survey item Q41: "Now, thinking about some possible economic concerns for the country: Do you think that the power of financial institutions and banks poses a major threat, a minor threat, or no threat to the economic well-being of (survey country)?"

- Debt.threat: coded from Survey item Q41: "Now, thinking about some possible economic concerns for the country: Do you think that the size of the national debt poses a major threat, a minor threat, or no threat to the economic well-being of (survey country)?"

- Inflation.threAt: coded from Survey item Q41: "Now, thinking about some possible economic concerns for the country: Do you think that rising prices pose a major threat, a minor threat, or no threat to the economic well-being of (survey country)?"

- Unemployment.threat: coded from Survey item Q41: "Now, thinking about some possible economic concerns for the country: Do you think that a lack of jobs poses 
a major threat, a minor threat, or no threat to the economic well-being of (survey country)?"

- Unions.threat: coded from Survey item Q41: "Now, thinking about some possible economic concerns for the country: Do you think that the power of financial institutions and banks poses a major threat, a minor threat, or no threat to the economic well-being of (survey country)?"

- Blame.govT: coded from Survey item Q16: "Who is most to blame for (survey country's) current economic problems? Is it our government?"

- Blame.BAnKs: coded from Survey item Q16: "Who is most to blame for (survey country's) current economic problems? Is it banks and other major financial institutions?"

- BLAme.US: coded from Survey item Q16: "Who is most to blame for (survey country's) current economic problems? Is it the United States?"

- BLAmE.EU: coded from Survey item Q16: "Who is most to blame for (survey country's) current economic problems? Is it the European Union?"

- Blame.Public: coded from Survey item Q16: "Who is most to blame for (survey country's) current economic problems? Is it the (survey country) public?"

- GEnDER: coded from Survey item Q141: "Gender (Interviewer record by observation)"

- AGE: coded from Survey item Q142: "How old were you at your last birthday?"

- InCOME: coded from Survey item Q156: L=low; $\mathrm{M}=$ medium; $\mathrm{H}=$ high; $\mathrm{X}=$ Refused

- EduCATIOn: coded from Survey item Q154: $\mathrm{P}=$ primary; $\mathrm{S}=$ secondary; $\mathrm{C}=$ college 


\section{Country-Level Variables}

- KOF.INDEX: KOF index of globalization from Dreher et al. (2008).

- Avg.Growth.2YRS: average level of growth in GDP per capita in 2011 and 2012; coded using the NY.GDP.PCAP.KD series of GDP per capita (constant 2005 US\$) from the World Bank, World Development Indicators.

- Time.since.last.elections: number of days elapsed since the last elections to the time the Survey was taken; coded from the Wikipedia pages for each country's elections.

- ENP: effective number of parties; coded using the data Michael Gallagher's Electoral Systems website at Department of Political Science, Trinity College Dublin (See also Gallagher and Mitchell, 2008).

\section{Descriptive Statistics}

\section{Accountability and Globalization Data Based on 2012 Pew Survey 26 Variables 8097 Observations}

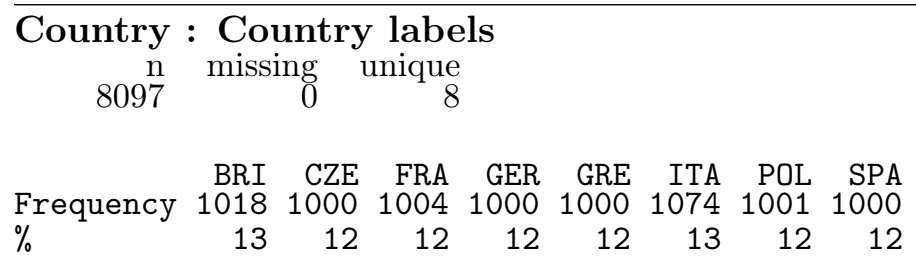


Avg.growth.2yrs : Average economic growth 2011-2012

$\begin{array}{rrrr}\text { n } & \text { missing } & \text { unique } & \text { Mean } \\ 8097 & 0 & 8 & -0.5065\end{array}$

$\begin{array}{lrrrrrrrr} & -6.9 & -1.4 & -1 & -0.1 & 0.4 & 0.5 & 1.9 & 2.6 \\ \text { Frequency } & 1000 & 1074 & 1000 & 1018 & 1000 & 1004 & 1000 & 1001\end{array}$

$\begin{array}{lllllllll}\% & 12 & 13 & 12 & 13 & 12 & 12 & 12 & 12\end{array}$

Time.since.last.elections : Days elapsed since last elections

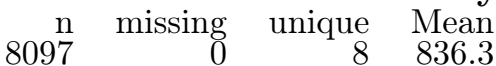

$\begin{array}{lrrrrrrrr} & 121 & 167 & 658 & 683 & 898 & 904 & 1435 & 1780 \\ \text { Frequency } & 1000 & 1001 & 1000 & 1018 & 1000 & 1000 & 1074 & 1004\end{array}$

$\begin{array}{lllllllll}\% & 12 & 12 & 12 & 13 & 12 & 12 & 13 & 12\end{array}$

ENP : Effective number of parties

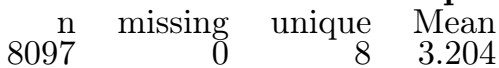

$\begin{array}{lllllllll}2.49 & 2.57 & 2.59 & 2.6 & 3 & 3.07 & 4.51 & 4.83\end{array}$

Frequency 10041018100010001001107410001000

$\begin{array}{lllllllll}\% & 12 & 13 & 12 & 12 & 12 & 13 & 12 & 12\end{array}$

Leader.job : Is incumbent leader doing a good job in dealing with European economic crisis

$$
\begin{array}{rrr}
n & \text { missing } & \text { unique } \\
7755 & 342 & 2
\end{array}
$$

Bad job $(3992,51 \%)$, Good job $(3763,49 \%)$

Country.ok : Assessment of general direction of country

$\begin{array}{rrr}\mathrm{n} & \text { missing } & \text { unique } \\ 7885 & 212 & 2\end{array}$

no $(6018,76 \%)$, yes $(1867,24 \%)$

Economy.now : Assessment of current economic conditions

$\begin{array}{rrr}n & \text { missing } & \text { unique } \\ 8034 & 63 & 2\end{array}$

$\operatorname{bad}(6314,79 \%), \operatorname{good}(1720,21 \%)$

Economy.next : Assessment of economic conditions in 12 months

$\begin{array}{rrr}n & \text { missing } & \text { unique } \\ 7998 & 99 & 3\end{array}$

better $(1718,21 \%)$, same $(2663,33 \%)$, worse $(3617,45 \%)$ 
Personal.economic.situation : Assessment of personal economic situation $\begin{array}{rrr}\mathrm{n} & \text { missing } & \text { unique } \\ 7978 & 119 & 2\end{array}$

$\operatorname{bad}(3627,45 \%), \operatorname{good}(4351,55 \%)$

Doing.better.financially : Assessment of family's economic situations compared to 5 years prior

$\begin{array}{rrr}n & \text { missing } & \text { unique } \\ 8039 & 58 & 3\end{array}$

no $(3967,49 \%)$, same $(2571,32 \%)$, yes $(1501,19 \%)$

Political.views : Political orientation: $\mathrm{L}=$ Left; $\mathrm{C}=$ Center; $\mathrm{R}=\mathrm{Right} ; \mathrm{X}=\mathrm{Refused}$ $\begin{array}{rrr}n & \text { missing } & \text { unique } \\ 8097 & 0 & 4\end{array}$

C $(5231,65 \%), \mathrm{L}(685,8 \%), \mathrm{R}(844,10 \%), \mathrm{X}(1337,17 \%)$

Banks.threat : Is the power of banks a threat to economic well-being $\begin{array}{rrr}n & \text { missing } & \text { unique } \\ 7841 & 256 & 2\end{array}$

no $(323,4 \%)$, yes $(7518,96 \%)$

Debt.threat : Is national debt a threat to economic well-being $\begin{array}{rrr}n & \text { missing } & \text { unique } \\ 7959 & 138 & 2\end{array}$

no $(179,2 \%)$, yes $(7780,98 \%)$

Inflation.threat : Is inflation a threat to economic well-being $\begin{array}{rrr}n & \text { missing } & \text { unique } \\ 7991 & 106 & 2\end{array}$

no $(235,3 \%)$, yes $(7756,97 \%)$

Unemployment.threat : Is Unemployment a threat to economic well-being $\begin{array}{rrr}n & \text { missing } & \text { unique } \\ 8037 & 60 & 2\end{array}$

no $(118,1 \%)$, yes $(7919,99 \%)$

Unions.threat : Are trade unions a threat to economic well-being $\begin{array}{rrr}\mathrm{n} & \text { missing } & \text { unique } \\ 7794 & 303 & 2\end{array}$

no $(2688,34 \%)$, yes $(5106,66 \%)$ 
Blame.govt : Government is to be blamed for economic problems $\begin{array}{rrr}n & \text { missing } & \text { unique } \\ 7914 & 183 & 2\end{array}$

no $(4666,59 \%)$, yes $(3248,41 \%)$

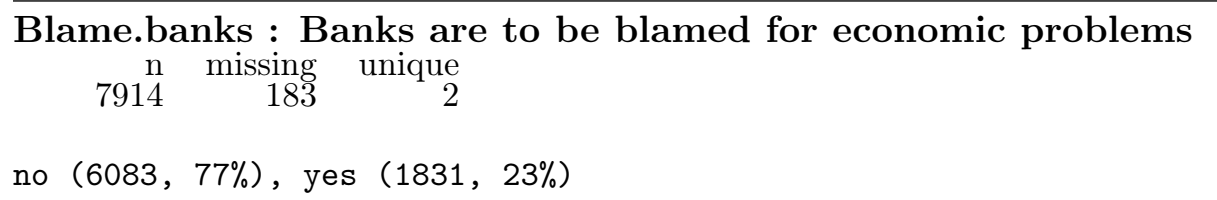

Blame.US : US is to be blamed for economic problems

$\begin{array}{rrr}n & \text { missing } & \text { unique } \\ 7914 & 183 & 2\end{array}$

no $(7796,99 \%)$, yes $(118,1 \%)$

Blame.EU : EU is to be blamed for economic problems

$\begin{array}{rrr}n & \text { missing } & \text { unique } \\ 7914 & 183 & 2\end{array}$

no $(7525,95 \%)$, yes $(389,5 \%)$

Blame.public : Public is to be blamed for economic problems

$\begin{array}{rrr}\text { n } & \text { missing } & \text { unique } \\ 7914 & 183 & 2\end{array}$

no $(7424,94 \%)$, yes $(490,6 \%)$

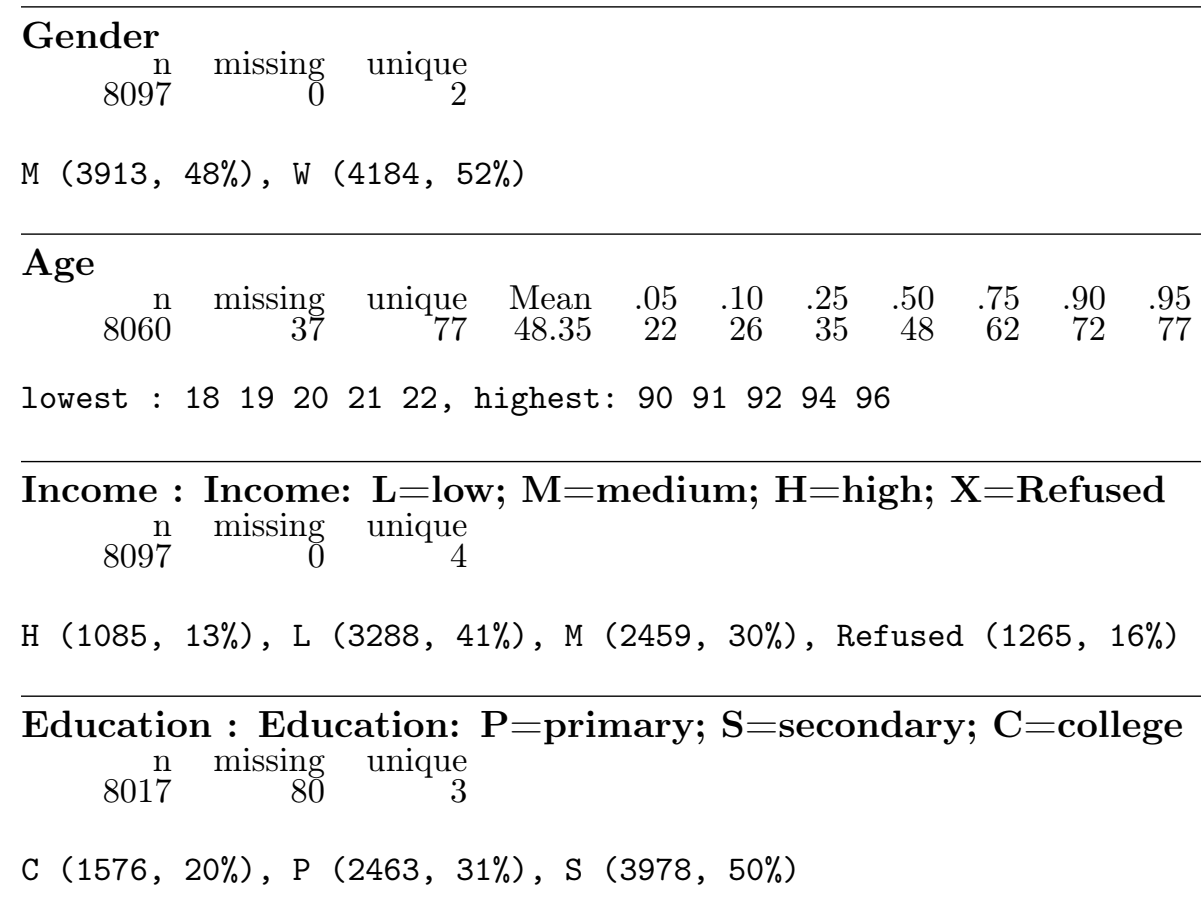




\section{Logistic Regression Model}

Table I: Logistic Regression Model (clustered S.E. by country)

\begin{tabular}{lc}
\hline \hline & Dependent variable: \\
\cline { 2 - 2 } & leader.job2 \\
\hline Country.ok=yes & $1.116^{* * *}(0.121)$ \\
Economy.now=good & $0.235(0.229)$ \\
Economy.next=same & $-0.634^{* * *}(0.139)$ \\
Economy.next=worse & $-1.281^{* * *}(0.235)$ \\
Personal.economic.situation=good & $0.304^{* *}(0.132)$ \\
Doing.better.financially=same & $0.275^{* *}(0.128)$ \\
Doing.better.financially=yes & $0.179(0.111)$ \\
Political.views=L & $-0.941^{* * *}(0.170)$ \\
Political.views=R & $0.123(0.240)$ \\
Political.views=X & $-0.522^{* * *}(0.119)$ \\
Banks.threat=yes & $-0.066(0.091)$ \\
Debt.threat=yes & $0.276(0.226)$ \\
Inflation.threat=yes & $-0.234(0.164)$ \\
Unemployment.threat=yes & $0.544^{* *}(0.258)$ \\
Unions.threat=yes & $0.381^{* *}(0.193)$ \\
Blame.govt=yes & $-0.918^{* * *}(0.201)$ \\
Blame.banks=yes & $-0.439^{*}(0.266)$ \\
Blame.US=yes & $-0.501(0.397)$ \\
Blame.EU=yes & $-0.590^{* * *}(0.228)$ \\
Blame.public=yes & $-0.222(0.220)$ \\
Gender=W & $0.107(0.079)$ \\
Age & $0.015^{* * *}(0.003)$ \\
Income=L & $-0.173(0.132)$ \\
Income=M & $-0.034(0.141)$ \\
Income=Refused & $-0.138(0.164)$ \\
Education=P & $-0.137(0.117)$ \\
Education=S & $-0.043(0.101)$ \\
KOF.index & $-0.040(0.050)$ \\
Avg.growth.2yrs & $-0.098(0.061)$ \\
Time.since.last.elections & $0.420(0.342)$ \\
ENP & $0.189(0.192)$ \\
Constant & $1.552(4.178)$ \\
\hline Observations & 4,830 \\
$\mathrm{R}^{2}$ & 0.347 \\
$\chi^{2}$ & $\mathrm{p}<0.01$ \\
\hline \hline Note: &
\end{tabular}




\section{R Session Info}

- $\mathrm{R}$ version 3.1.1 (2014-07-10), x86_64-pc-1inux-gnu

- Base packages: base, datasets, graphics, grDevices, grid, methods, splines, stats, stats4, utils

- Other packages: caret 6.0-35, classInt 0.1-21, Formula 1.1-2, ggplot2 1.0.0, gridExtra 0.9.1, knitr 1.6, lattice 0.20-29, MASS 7.3-34, modeltools 0.2-21, multilevel 2.5, nlme 3.1-117, party 1.0-16, plyr 1.8.1, RColorBrewer 1.0-5, rworldmap 1.3-1, sandwich 2.3-2, scales 0.2.4, sp 1.0-15, SparseM 1.05, stargazer 5.1, strucchange 1.5-0, survival 2.37-7, xtable 1.7-3, zoo 1.7-11

- Loaded via a namespace (and not attached): BradleyTerry2 1.0-5, brglm 0.5-9, car 2.0-21, class 7.3-11, cluster 1.15.3, codetools $0.2-9$, coin 1.0-23, colorspace 1.2-4, digest 0.6.4, e1071 1.6-4, evaluate 0.5.5, fields 7.1, foreach 1.4.2, foreign 0.8-61, formatR 1.0, gtable 0.1.2, gtools 3.4.1, Hmisc 3.14-4, iterators 1.0.7, labeling 0.3, latticeExtra 0.6-26, lme4 1.1-7, maps 2.3-7, maptools 0.8-30, Matrix 1.1-4, minqa 1.2.3, munsell 0.4.2, mvtnorm 1.0-0, nloptr 1.0.4, nnet 7.3-8, proto 0.3-10, Rcpp 0.11.2, reshape2 1.4, rms 4.2-0, spam 0.41-0, stringr 0.6.2, tools 3.1.1 